\title{
Brief Analysis on Business Model Innovation of Digital Music
}

\author{
Lin Yu and Ruiping Zhang \\ College of Music, Jiangxi University of Technology
}

Keywords: Digital Music; Commercial Model; Innovation

\begin{abstract}
The development of digital technology has an overturning impact on music industry in the network era; the traditional record companies have to implement the digital transformation, because new competitive forces are joining the industry chains, such as network music operators, value-added service providers, terminal equipment manufacturers and even mobile operators who aim to lead the development of music industry with its music data services; the competition and integration of various forces all provide a profound potential prospect for future digital music development. However, piracy has been the recurring troubles of Chinese music market, meanwhile, the development of network technologies, such as search and P2P have facilitated the growth of online piracy, even trying to redefine the meaning of copyright law, which made the protection of digital copyright in a sea of troubles. Although there are benefits from digital music on ring back music gain sharing, the mature business model still needs to be explored in practice, in order to get return of value from original whole piece of music. Along the innovative thinking of mesoscopic approach to business models, using mature business models and design ideas summarized by predecessors, combining the inherent law of digital music industry development, focusing on the core value proposition of digital music industry, the innovative form of digital music business model can be explored. The "iPod+iTunes" model of Apple Company and ring back music model of China Mobile show us the huge value of digital music innovative model. Each link of digital music industry chain makes use of the value space provided by Internet, focuses on content or channel or the platform, with various innovation ways, and obtains great value promotion for users with lower costcreating the blue ocean of digital music. Finally, users will have more choices and be convenient in the music consumption by the value innovation, and enjoy rich high perceptual music experience.
\end{abstract}

\section{Introduction}

Digital music has already quietly permeated people's life; the earliest CD player, the current popular MP3 player and network music are all the various forms and contents gradually evolved from digital music.

Digital technology is adopted in CD, VCD and DVD, which have higher degree of acoustic fidelity than MP3, but they can only be applied in traditional music industry rather than transferred on internet. Long before MP3, PC users recorded, downloaded and played high-quality sound files with the format named WAV, but the format didn't come into fashion due to large file and inconvenient transmission. Until the popularity of MP3 on the internet that brought new model of music consumption, the trend of digital music was being swept across and gradually overturned traditional music ecology. Therefore, the paper defined the digital music as using digital technology in the process of music production, propagation and storage, and the music that can be transferred through internet and wireless network. The common digital music formats include MP3, WMA, etc. 
In 1996, MP3 audio compression technology appeared, and it could compress the capacity of CD music into only several MB, which made the free sharing on the internet possible. Most of the music lovers would transform their CD into MP3 format at that time when the technology was introduced, and upload their music on the internet for free download of other users, which was the main source of the MP3 music at the time. With the development of computer and Internet, a new virtual network society built created basic condition for the music ind ustry digitization. Along with the breakthrough of music communication, carry, appreciation convenience as well as the great changes of copyright protection and consuming behavior, "creative destruction" said by Schumpeter appeared in music industry, and digital music industry with completely different characteristics from traditional music industry was born.

Digital music analysis. According to Statistical report on China internet network development status issued by China Internet Network Information Center, the internet has entered the fast development period in China. The growth of total internet users provides great market growth potential for digital music; industry environment has been changed and new industry appears because of these internet characteristics. Porter's five forces were applied in the discussion on the influence of internet to profitability of digital music industry. In addition, the characteristics of Internet media and network externality tends to acquire valued customers who may not make payments. There are actually two types of interconnected customers in music website, who are music download users and advertisers; the two types of competition are music download and the ads for buying or selling things in the website. The competitors include not only other music websites, but also other portals, even newspaper, TV and other media, in which the ads are the same as in music websites or used to be. Music has a long history, but it is not a long history for music as one industry with great development, and with general public as the music products consumers. In early stage, the business model of music industry was achieved by selling coins for jukebox, and the great inventor Thomas Edison became the industry tyrant through patent monopoly of phonograph at that time. With the development of economy and technology and clear legal position of music copyright, the traditional business model of music industry was gradually formed. The appearance of digital music makes a strong impact on traditional record industry.

First of all, the emergence of digital music directly affects the foundation of survival for traditional music industry, which is the production and circulation of music products. Through the combination of developed wireless value-added technology and broadband network, digital music provides the platform for majority of singer-songwriters to express original music. The popularity of the songs depends on the viewers on the internet, and the popular songs can be quickly spread through click rates on the internet, which reduce the threshold for singer-songwriters to show their music talents, and greatly promote the development of music industry.

Second, digital music greatly shortens the music production cycle. In traditional music industry, it takes a long time for a song to be heard by audiences; the hype of singers and record propaganda would be extremely costly and trivial. However, digital music can achieve profit quickly through organic wireless and wired combination, which saves the hype and propaganda of brokerage firms, speeds up the music promotion and facilitates the communication. As a new form of digital music consumption, the emergence of ring back music revives the whole Chinese record industry. Almost all the record companies take the wireless value-added market as their major source of income in future. It's difficult to get profits by selling music in the past; on the contrary, the ring back music can bring profits for companies at present. 
According to the situation of current market consumption, there are mainly two kinds of charging download services: single song downloads and monthly downloads. Single song download is the most common charging mode, in which each song is charged with certain price. The bounded sales promotion can also be used in single song download.

At present, the two profit sources for P2P websites are: firstly, charge of software, which is to make use of the software and resources provided by the website, such as Kazaa, PP, and Kuro providing monthly download with charges; secondly, network ads, which is to embed ads in the homepage or software, and create profits through visitor volume of Page View and usage amount of software, such as Kugoo, POCO, etc.

At present, Kugoo is one of the biggest P2P music sharing software. Since the foundation in 2003, Kugoo has been committed to provide users more comprehensive in-depth experience of music. Through the architecture of P2P technology, Kugoo realizes fast research and high-speed download of music files. Besides the basic function of music player as one kind of music software, Kugoo also has the function of making friends, such as users chat and file transmission like common chatting software. What's more, Kugoo provides music magazine service, including music blog, music forum, music community, music store, etc. Almost all the necessary music services are included. Kugoo continuously creates happiness for the users and brings happy entertainment products of Kugoo. The "programs of net friends", "doghouse" and "paradise" were deeply loved, and became the happy products among users. On the use of music, Kugoo provides the most excellent play experience, with ultra-strong karaoke lyrics function, which has the most mature lyrics technology in China. In particular, its original "program" becomes the new issuing way; lots of music companies and artists release their digital albums through "program"; Kugoo innovates and leads digital music is suing way. Kugoo software is free, but its main source of income is the embedded web advertising in the software.

The definitions of business model are varied from different angles. Focusing on business model innovation, based on the theoretical framework of business model innovation in Business model innovation-launch of enterprise management Rubik's cube by Professor Weng Junyi of Xiamen University, introducing the interactive interface of internal environment with platform environment, customer environment, partner environment and roof environment, the platform interface, customer interface, partner interface and roof interface are formed, and the internal structure overlapped with internal environment, of which the customer interface, internal structure and partner interface form the core interface of basic enterprise operating activities, and platform interface and roof interface form the relation interface.

The song Mice love rice was created by unknown and plain-looking singer Yang Chengang in 2000. After being rejected by record companies, Yang began to transfer the copyright of his song here and there, successively to Tian Chuanjun, Wang Hu, Shi Yan and Feile Record company later, which led to copyright suits; in the tide of MP3 free download, numerous MP3 download websites emerged overnight; various versions including singing while playing guitar, Wang Qiwen, and Disco are all put online, of which the Wang Qiwen version and Disco version became popular; in 2004, the girl version by Xiangxiang, a singer on the internet, who belonged to Feile Record appeared.

The P2P digital music sharing model was a headache for record companies; Napster, the biggest digital music exchange website in the US was judged as illegal by Courts of Appeals in February, 2001 because the website provided users the central server function for sharing digital music. In fact, similar cases happened a lot in the US, which made it increasingly inconvenient to download free 
music from internet through $\mathrm{P} 2 \mathrm{P}$ model; some websites developed legal but poorly convenient distributed P2P structure, but record companies began to sue the users through P2P download, which made the downloader be greatly upset.

Meanwhile, RIAA began to publicize the unauthorized download of digital music as wrongdoing to the public through media, which had an effect among the public.

The aim of record companies is to spare none the unauthorized digital music, however, from 2001 to 2003, when record companies won a series of victories, Jobs, CEO of Apple, saw the chance of paying to download as the unparalleled convenience of digital music download from internet than buying record due to numerous plays in PC and MP3; now that the online illegal download suffered a hard hit from record companies, can the paid download be accepted by consumers?

It was indeed a good year in 2003, under the years of lawsuits and moral dissuasions of record companies, the majority of digital music lovers potentially would like to find a legal way to enjoy music. The online music store, iTunes of Apply Company occupies $70 \%$ of the market shares of global online music market at present.

The success of Apple model presented the classic case of exploring the value from the new consumption model of traditional products: firstly, Apple discovered paid download model of digital music and its potential consumers, and put into practice at the right moment; secondly, the extraordinary work of Apple in exploring consumers changes the potential consumers who are used to downloading for free into the users of iTunes. To understand the time and reason for the appearance of potential consumers, let's start with the change of US digital music market itself. The later successful iTunes opened up in April, 2003, and the prospects of digital music remain undecided before that time due to wide lawsuits.

Due to the strike of digital music, the sales of US record declined with the speed of around $10 \%$ each year from 2000 to 2003, and record companies had to defend their rights by using laws as a weapon.

In the United States, there is no website for MP3 free download openly, because it's forbidden by law. Polyphonic ringtone also called ring back music, which only exists as the ring tone while waiting for the answering, and it can't be transferred among users. About four years ago, Korean invented the ring back music industry in order to add a few small functions on the switch. At home, Huawei and ZTE also developed and recommended the technology to China Mobile and China Unicom, who all adopted the skill and applied it in the business. Actually, there is no coherent idea about the process of ring back music, and people are most familiar with the simplest application proposed by that time. This new technology can also provide a lot of other applications, such as background music service, in which there will be background music played when you are taking on the phone, and other complicated settings for ring back music, including different ring back music from different callers or different rings in different time. However, these applications may be too complicated, or perhaps it is not necessary, so the users are much less enthusiastic; the simplest ring back music business is highly sought after among the consumers, and it's not an advanced technology.

One of the features in some market is that multiple providers and customers exchange with each other, and both of them bear high transaction cost. Usually, this situation will lead to an intermediary business with high value. This business acts as a distributor, with the function of building one communication platform from various aspects, whose value is to reduce the cost of buyers and sellers (including money and mental and physical burden). 
The system can monitor all kinds of pirated online music download service, and quickly find out who is pirating and the speed of pirating. On the discovery of piracy, it will be recorded and the information will be sent to the record company, songwriter, or various copyright owners.

\section{Conclusions}

Brief analysis on innovation of digital music business model

Add communication and emotion orientation if possible, and develop another new profit source of music products sales, which directly turns around the situation of earning money by selling music for China record industry. With enclosed digital music sales system, complementary products which give customers first-class experience, Apple model opens up digital music sales channel that is to sell music rather than record, and this is of great prospects. Apple Company provides high-quality sound effect music creatively in iTunes; it's easily navigated, searched and browsed, and the services are much better than the free download.

Combined with perfectly designed product iPod music player, iTunes only allows the iPod users to conveniently download and buy music. With the model of "first-class profits from first-class products", the iPod as the embodiment of personality and fashion blended in the iTunes music download services, integrate the paid download and brand experience, finally users accept the convenient online music consumption experience as one way of music consumption.

Each kind of innovation for digital music business model is the extension of the digital music. The content model of digital music opens up the blue seas for net songs and grassroots singers. Music content production is no longer mastered by the elite with say such as the record company; from the aspect of "anti-elite", the mass can create more so-called "vulgar" music products that are suitable to public emotion needs through network, and greatly enrich the music content. Digital music channel model opens up the blue sea for new digital music consumption. The new consumption way facilitates music consumption, provides more music styles for choice, shares and communicates music feelings with others, expands the knowledge of music and acquires more emotional experience. The blue sea strategy of digital music is to achieve the innovation of music industry value using internet, create the music service business model with lower cost and higher value.

\section{Acknowledgements}

Jiangxi art planning project: "feasibility of industrialization of jiangxi private performing arts market operation analysis for nanchang new zhongyuan grand theatre, for example" project (No YZ2014081)

\section{References}

[1] Teece D J. Business models, business strategy and innovation[J]. Long range planning, 2010, 43(2): 172-194.

[2] Trott P. Innovation management and new product development[M]. Pearson education, 2008.

[3] Hughes J, Lang K R, Vragov R. An analytical framework for evaluating peer-to-peer business models[J]. Electronic Commerce Research and Applications, 2008, 7(1): 105-118.

[4] Lucchi N. Intellectual Property Rights in Digital Media: A Comparative Analysis of Legal Protection, Technological Measures and New Business Models under EU and US Law[J]. Buffalo 
Law Review, 2005, 53(4).

[5] Dou W, Chou D C. A structural analysis of business-to-business digital markets[J]. Industrial marketing management, 2002, 31(2): 165-176.

[6] Clemons E K, Lang K R. The decoupling of value creation from revenue: A strategic analysis of the markets for pure information goods[J]. Information Technology and Management, 2003, 4(2-3): 259-287.

[7] Jantz R C. E-Books and New Library Service Models: An Analysis of the Impact of EBook Technology on Academic Libraries[J]. 2001.

[8] Rupp P, Estier T. A model for a better understanding of the digital distribution of music in a peer-to-peer environment[C]/System Sciences, 2003. Proceedings of the 36th Annual Hawaii International Conference on. IEEE, 2003: 11 pp.

[9] Fox M. E-commerce business models for the music industry[J]. Popular Music and Society, 2004, 27(2): 201-220.

[10] Yovanof G S, Hazapis G N. Disruptive technologies, services, or business models?[J]. Wireless Personal Communications, 2008, 45(4): 569-583. 